\title{
Management of some seed-borne pathogens attacking alfalfa plants in Saudi Arabia
}

\author{
Al-Askar, A.A. ${ }^{1}$, Ghoneem, K.M ${ }^{2}$ and Rashad, Y.M ${ }^{1^{*}}$ \\ ${ }^{1}$ Science Department, Teachers College, King Saud University, Riaydh, Saudi Arabia. \\ ${ }^{2}$ Department of Seed Pathology Research, Plant Pathology Research Institute, Agricultural Research Center, Giza, \\ Egypt.
}

Accepted 19 March, 2013

\begin{abstract}
Management and transmission of four seed-borne pathogenic fungi namely, Colletotrichum trifolii, Rhizoctonia solani, Fusarium equiseti and $F$. incarnatum were investigated on alfalfa plants. The pathogenicity test on alfalf plant showed that $\boldsymbol{R}$. solani and $\boldsymbol{C}$. trifolii caused high percentages of rotted seeds and seedlings mortality $(26.45,26.1 \%$ and $31.6,21.1 \%$, respectively). However, no significant differences were observed between the treatments with $F$. equiseti and $F$. incarnatum when compared with the control treatment. Transmission of the pathogenic fungi from seed to mature plant of alfalfa was investigated in this study. Results indicate that the recovery percentages of the tested pathogens gradually decreased from root apex up to the first internodes below the shoot tip, but did not reach to the shoot apex. In order to control these fungi, different concentrations of sodium metabisulphite (SM), sodium salicylate (SS) and hydroquinone (HQ) were tested in vitro. Treatment with SM at $10 \mathrm{mM}$ completely inhibited the growth of all isolated fungi. Under greenhouse conditions, soaking alfalfa seeds in a water solution of hydroquinone at $12 \mathrm{mM}$ showed to be the most effective treatment in reducing seed rot and seedling mortality percentages and increasing seedling survival percentages. Application of the tested treatments presented significant increases in growth parameters, photosynthetic pigments (chlorophyll $a$ and $b$ and carotenoids) in leaves and total phenol in alfalfa plants. This study therefore recomended the use of $H Q$ and $S M$ as potential and promising antifungal agents in the protection of alfalfa plants against the tested seed-borne fungi.
\end{abstract}

Key words: Pathogenicity, Colletotrichum trifolii, Rhizoctonia solani, Fusarium equiseti, F. incarnatum, transmission, hydroquinone, sodium metabisulphite and sodium salicylate.

\section{INTRODUCTION}

Alfalfa (Medicago sativa L.) is the oldest and most important forage crop in the world. In Saudi Arabia, it is widely cultivated and comes to be the first cultivated forage crop and occupies more than $30 \%$ of the cultivated area (Al-Askar et al., 2012). In 2012, the cultivated area under alfalfa in Saudi Arabia was 122,563 hectares, which produced 2,528441 tons. Cultivation is mainly in Riyadh (62879 ha) area of the Kingdom with an average production of 1,264579 tons (Agriculture
Statistical Yearbook, 2012).

Seed-borne disease refers to the particular plant diseases that are transmitted by seed. In some cases the transmission on seed is insignificant compared to the population of disease organisms that exist in soil or on weed species. In other cases, the transmission on seed is the primary means by which a disease spreads. Seed transmission studies help to confirm the seed to plant transmission to prove the pathogenicity and to design the 
suitable management strategy (Neergaard, 1979). No extensive work on the prevalence of seed-borne fungi and their transmission from seed to seedling of alfalfa seeds has been done in Saudi Arabia. Moreover, every year seed-borne fungi cause heavy yield loss of the crop and some fungi act as a primary source of infection.

Various fungal soil-borne pathogens attack alfalfa plants causing a reduction in the stand establishment, yield, forage quality and longevity. Anthracnose disease caused by the fungus Colletotrichum trifolii (Bain and Essary), is a common problem in alfalfa. The disease affects leaves, stems, and crowns, but crown rot is the most important symptom of the disease. The fungus persists in alfalfa debris and crowns. During the growing season (late summer and early fall), the produced spores in stem lesions transmit by splashing rain and irrigation wither onto growing stems and petioles (Vasić et al., 2010). In this respect, O'Neill and Saunders (1994) reported that C. trifolii can infect susceptible alfalfa cotyledons by directly penetrating the epidermis via a penetration peg that form the appressorium. Appressoria and primary hyphae maturate within $20 \mathrm{~h}$ on cotyledons, while the secondary spores are produced on susceptible tissues after $96 \mathrm{~h}$.

Rhizoctonia solani Kühn, is the causative of seedling damping-off and crown and root rot diseases. In winter, the fungus persists (inactive) in infected root sunken lesions, which will turn black. If roots are girdled during summer, the plant will die. The fungus can also infect the crown at the location where new buds emerge and move into the crown, killing tissue (Frate and Davis, 2007).

Fusarium rot disease of alfalfa is caused by Fusarium species complex. F. incarnatum Berk. \& Rav. and $F$. equiseti (Corda) Sacc. are reported as the causal agents of crown and root rot diseases. Except rot, symptoms of the disease are manifested in the form of chlorosis of leaves and lower plants (Couture et al., 2002; Krnjaja et al., 2003; Zaccardelli et al., 2006). Affected seedlings of alfalfa show brownish discoloration and water-soaking symptoms as well as rotting of seeds. Diseased tissues from affected alfalfa plants was found to contain the mycotoxins, nivalenol and (or) zearalenone (Goswami et al., 2008).

Spores, mycellium particles and/or sclerotia of the $C$. trifolii and $R$. solani may also be spread by seed contaminated during the threshing process (Neergaard, 1979; Frate and Davies, 2007). Fusarium species were isolated also from alfalfa seed (Krnjaja et al., 2003; Mathur and Manandhar, 2003), which could be a source of further spreading of pathogens on vegetative parts of the plant and cause problem in establishing of alfalfa crops. Recently, C. trifolii, R. solani, F. incarnatum and F. equiseti have been reported as important potential seedborne pathogens on alfalfa in Saudi Arabia (Al-Askar et al., 2012).

Control of seed-borne fungi is currently limited to the use of protecting fungicides (Thomas and Sweetingham,
2003). Increasing knowledge and concerns about the environmental consequences of repeated fungicide applications have prompted the industry and research scientists to explore the potential of alternative strategies, including the use of environmentally alternatives for controlling the diseases without toxicity on plants, animals or human. Many investigators reported the effectiveness of some antifungal substances for seed, soil and foliar treatment (Shabana et al., 2008; Abd El-Hai et al., 2009). Hydroquinone, which synthesized naturally in the leaves, bark and fruit of a number of plants, especially the ericaceous shrubs such as cranberry, cowberry, bearberry and blueberry is reported to be a potential inhibitor for some seed-borne pathogenic fungi of peanut (El-Wakil and El-Metwally, 2000). Sodium salicylate is a sodium salt of salicylic acid, and involved in reducing the sour rot caused by Geotrichum candidum in the mandarin fruit (Talibi et al., 2011). Sodium metabisulfite which is known as medical antiseptic is widely used as a multi-functional antimicrobial gent and is a common preservative used in relishes, fresh and dried fruits and vegetables, tomato paste and mincemeat (Ash and Ash, 2009). Several reports presented their effectiveness in inhibiting mycelial growth and sporulation of many fungal pathogens at different concentrations (Hervieux et al., 2002; Mills et al., 2004).

Considering the seriousness and common occurrence of seed rot of alfalfa in Saudi Arabia and inadequate information regarding the seed-borne fungi and their transmission from seeds to seedlings, this study was undertaken to study the nature of the isolated fungi and elucidate the mode of transmission of some pathogenic fungi (C. trifolii, F. equiseti, $F$. incarnatum and $R$. solani) from seed to mature plant. The effect of hydroquinone (HQ), sodium salicylate (SS), and sodium metabisulfite (SM) on the isolated seed-borne pathogens of alfalfa was also investigated.

\section{MATERIALS AND METHODS}

\section{Chemicals and alfalfa seeds}

The three tested chemicals were obtained from Sigma Chemicals Co., USA. Rhizolex-T 50 W.P was obtained from Somatco Chemicals, Saudi Arabia. Seeds of local alfalfa cultivar (Hegazy) obtained from growing fields of Riyadh region, Saudi Arabia during 2011 were used in this study.

\section{Pathogenic fungi}

Four fungal species that is $C$. trifolii, $R$. solani, $F$. equiseti and $F$. incarnatum were isolated from seeds surfaces of local alfalfa cultivar (Hegazy) collected from growing fields of Riyadh region in Saudi Arabia (Al-Askar et al., 2012). Conventional seed health testing was carried out to detect fungi associated with alfalfa seeds (ISTA, 1999). The isolated fungi were grown on potato dextrose agar (PDA) (Difco, USA) plates supplemented with antibacterial agent (L-chloramphenicol $5 \mathrm{mg} / \mathrm{L}$ and streptomycin sulphate $5 \mathrm{mg} / \mathrm{L}$ ) and incubated at $28^{\circ} \mathrm{C}$ for 4 to 6 days. Purification of the resulting 
isolates was done using the hyphal tip or single spore techniques to obtain pure cultures; the detected isolates were then transferred into slant of PDA and kept at $4^{\circ} \mathrm{C}$ for further studies. Pure cultures of the isolated fungi were identified according to their cultural properties, morphological and microscopical characteristics as described by Booth (1977) and Domsch et al. (1980).

\section{Transmission of seed-borne fungi in alfalfa}

\section{Preparation of inocula}

Flasks contaning $50 \mathrm{ml}$ of potato dextrose broth were inoculated singly with disks ( $7 \mathrm{~mm}$ in diameter) taken from the growing edge of 5 -day-old colony of each fungus. The flasks were then incubated in dark (without shaking) for 10 days at $25 \pm 2^{\circ} \mathrm{C}$. Fifty grams of each mycelial mat were harvested and blended in $500 \mathrm{ml}$ of sterile distilled water to produce fungal suspensions.

\section{Pathogenicity test}

Healthy alfalfa seeds were surface sterilized in 1\% sodium hypochlorite solution. The disinfected seeds were then soaked in the fungal suspensions containing $2 \%$ Arabic gum for $15 \mathrm{~min}$ and left to dry at room temperature. Control treatment was carried out by soaking the disinfected seeds in tap water. Ten seeds per pot of alfalfa were planted in $20 \mathrm{~cm}$ diameter plastic pots containing sterile soil $(2 \mathrm{~kg}$ soil/pot). The seeds were allowed to grow under greenhouse conditions. Ten replicates were used for each treatment. Daily observation for germination and symptoms of pre- and postemergence damping off were recorded for two months.

\section{Transmission study}

Alfalfa plants surviving the challenge with the selected seed borne fungi in the pathogenicity test were left to grow until maturity. After 60 days of planting, 20 plants were pulled from their pots, washed, and surface sterilized. Under sterile conditions, alfalfa plant were cut into different parts including, root, crown, basal stem (from soil surface up to $10 \mathrm{~cm}$ ), middle stem (from 10-15 cm) and upper stem (from $15-20 \mathrm{~cm}$ ) and stem apex. The plant parts were then transferred into PDA plates supplemented with antibacterial agent (Lchloramphenicol $5 \mathrm{mg} / \mathrm{L}$ and streptomycin sulphate $5 \mathrm{mg} / \mathrm{L}$ ). The plates were then incubated for 4 days at $24 \pm 2^{\circ} \mathrm{C}$ under cool white fluorescent light with alternating cycles of $12 \mathrm{~h}$ light and $12 \mathrm{~h}$ darkness. Fungi recovered from each treatment were identified and the transmission percentage was recorded.

\section{Evaluation of the antifungal activity of tested substances in vitro}

The antifungal activity of the tested substances was evaluated on the linear growth of the pathogenic fungi. Seven concentrations $(0$, $4,6,8,10,12$ and $14 \mathrm{mM}$ ) of each substance were incorporated in PDA plates by adding the appropriate amount of each substance aseptically to the melted medium just before solidification. The chemical fungicide Rhizolex-T 50 W.P. at rate of $3.0 \mathrm{~g} / 1000 \mathrm{ml}$ was used as positive control. Plates without any additions were used as a negative control. Disks ( $7 \mathrm{~mm}$ in diameter) taken from the growing edge of 5-day-old colony of each fungus were used to singly inoculate the prepared plates. The plates were incubated at $25 \pm$ $2^{\circ} \mathrm{C}$ for 6 days. Five replicate were used per treatment. The fungal growth was measured after 3 and 5 days from incubation and the average growth diameter was calculated.
Greenhouse evaluation of the antifungal activity of tested substances

Inocula of the isolated pathogens were grown on sterilized medium of sorghum: coarse sand: water $(2: 1: 2 \mathrm{v} / \mathrm{v})$. Plastic pots $(40 \mathrm{~cm}$ diameter) filled up with $4 \mathrm{~kg}$ autoclaved clay soil and singly infested with the previously prepared inocula at the rate of $0.5 \%$ by weight Pot soil were mixed thoroughly with inoculum then, watered and left for one week to ensure even distribution of the inoculated fungi. Ten pots were used as replicates for each treatment as well as control treatment (uninfested soil).

Apparently healthy alfalfa seeds were surface sterilized in $1 \%$ sodium hypochloride followed by soaking them in solutions of $\mathrm{HQ}$ (10 and $12 \mathrm{mM})$, SM (8 and $10 \mathrm{mM}$ ) and Rhizolex-T 50 (2.5 g/1000 $\mathrm{ml}$ ) for three hours and then dried using sterilized paper. The negative control treatment was prepared by soaking healthy seeds in sterilized water. Ten seeds were planted in each pot (one week after inoculation with the fungi) and replicated ten times for each treatment. Pots were watered regularly to near field capacity with tap water. All pots were arranged in a completely randomized design and kept in a greenhouse under natural conditions (day temperature $25^{\circ} \mathrm{C}$, night temperature $20^{\circ} \mathrm{C}, 16 \mathrm{~h}$ photoperiod). The disease incidence was determined visually by recording the percentage of unemerged seeds 10 days after sowing as well as percentage of dead seedlings 45 days after sowing.

After 45 days of sowing, ten plants were randomly selected from each treatment for growth evaluation. Plant height, root and shoot length, number of branches, shoot fresh and dry weight, and leaf area were determined. The total phenolic content was determined in the shoots according to the study of Malik and Singh (1980). Photosynthetic pigments (Chlorophyll $a$, Chlorophyll $b$ and Carotenoids) were estimated in the leaves using the spectrophotometric method as described by Harborne (1984).

\section{Statistical analysis}

All data were subjected to analysis of variance using the statistical analysis software "CoStat 6.4" (CoStat 2005). Comparisons among means were made using Duncan's multiple range test at $P \leq 0.05$ (Duncan, 1955).

\section{RESULTS}

\section{Pathogenicity test}

Growing-on-test showed that the disease symptoms in the treatments of the two Fusarium species were similar in forming of rotted seeds, yellow seedlings and diseased but healthy looking plants. Infection with $R$. solani and $C$. trifolii presented leaf blight, seed rot and seedling damping-off. Following-up the growing-on-test two months later, results indicated that, most tested fungi caused mild to severe infection in alfalfa plants. $C$. trifolii and $R$. solani showed the highest percentages of rotted alfalfa seeds (31.6 and $26.45 \%$, respectively), followed by $F$. equiseti $(17.45 \%)$ and $F$. incarnatum (15.7\%), which is not significant as compared to the check (1.6\%). In case of Fusarium spp., it produced whitish fluffy colony on the seeds and around the base of seedlings. On the other hand, symptoms of seedling motality caused by $R$. solani developed the highest infection percentage (26.1\%), while $C$. trifolii developed $21.1 \%$ infection, followed by $F$. 
Table 1. Pathogenicity of isolated fungi from alfalfa seeds and the type of symptoms occurred when seed inoculation technique was used under greenhouse conditions*.

\begin{tabular}{lccc}
\hline Treatment & \% Rotted seed $^{\mathbf{1}}$ & \% Infected seedling $^{2}$ & \% Healthy seedling $^{\mathbf{2}}$ \\
\hline Control & $1.60 \mathrm{~b}$ & $0.0 \mathrm{~b}$ & $98.4 \mathrm{a}$ \\
C. trifolii & $26.45 \mathrm{a}$ & $21.1 \mathrm{a}$ & $52.45 \mathrm{c}$ \\
F. equiseti & $17.45 \mathrm{ab}$ & $16.45 \mathrm{ab}$ & $66.1 \mathrm{~b}$ \\
F. incarnatum & $15.7 \mathrm{ab}$ & $9.8 \mathrm{~b}$ & $74.5 \mathrm{~b}$ \\
R. solani & $31.6 \mathrm{a}$ & $26.1 \mathrm{a}$ & $42.3 \mathrm{c}$ \\
\hline
\end{tabular}

${ }^{*}$ Affected plants with different fungi in the pathogenicity test were determined during seedling growth stage as:

${ }^{1}$ Pre-emergence damping- off (rotted seeds)

${ }^{2}$ Post- emergence damping- off (infected seedlings).

Values within a column followed by the same letter(s) are not significantly different according to Duncan's multiple range test $(P \leq 0.05)$.

Table 2. Incidence of the pathogenic fungi in different parts of alfalfa.

\begin{tabular}{lcccccc}
\hline & \multicolumn{7}{c}{ Fungal incidence (\%) } \\
\cline { 2 - 7 } Fungus & Root & Crown & $\begin{array}{c}\text { Basal } \\
\text { stem }\end{array}$ & $\begin{array}{c}\text { Middle } \\
\text { stem }\end{array}$ & $\begin{array}{c}\text { First internode from } \\
\text { shoot tip }\end{array}$ & $\begin{array}{c}\text { Stem } \\
\text { apex }\end{array}$ \\
\hline Control & $0.0 \mathrm{~d}$ & $0.0 \mathrm{~d}$ & $0.0 \mathrm{c}$ & $0.0 \mathrm{~b}$ & $0.0 \mathrm{~b}$ & $0.0 \mathrm{a}$ \\
C. trifolii & $83.3 \mathrm{a}$ & $50.0 \mathrm{~b}$ & $33.4 \mathrm{a}$ & $11.7 \mathrm{a}$ & $3.3 \mathrm{a}$ & $0.0 \mathrm{a}$ \\
F. equiseti & $34.1 \mathrm{c}$ & $17.0 \mathrm{c}$ & $0.0 \mathrm{c}$ & $0.0 \mathrm{~b}$ & $0.0 \mathrm{~b}$ & $0.0 \mathrm{a}$ \\
F.incarnatum & $35.0 \mathrm{c}$ & $67.0 \mathrm{a}$ & $0.0 \mathrm{c}$ & $0.0 \mathrm{~b}$ & $0.0 \mathrm{~b}$ & $0.0 \mathrm{a}$ \\
R. solani & $66.2 \mathrm{~b}$ & $67.0 \mathrm{a}$ & $11.4 \mathrm{~b}$ & $0.0 \mathrm{~b}$ & $0.0 \mathrm{~b}$ & $0.0 \mathrm{a}$ \\
\hline
\end{tabular}

Values within a column followed by the same letter(s) are not significantly different according to Duncan's multiple range test $(P$ $\leq 0.05)$.

equiseti (16.45\%). The lowest pathogenic one was $F$. incarnatum (9.8\%). Disease symptoms were expressed as necrotic root tissue varied from light brown to explicit black. Necrotic tissue of the root was rotten and decayed (Table 1).

\section{Transmission of the pathogenic fungi}

Data presented in Table 2 show the incidence of the tested pathogens on different parts of the alfalfa plants. The highest incidence percentage on the root part was that of $C$. trifolii (83.3\%) while, $F$. incarnatum and $R$. solani were found on the crown part $(67 \%)$. On the other hand, $C$. trifolii solely recovered from middle and upper stem parts (11.7 and $3.3 \%$, respectively). Isolation trials from different plant parts showed that $F$. equiseti and $F$. incarnatum were restricted to root and crown parts. However, results indicated that the recovery percentages of the tested pathogens gradually decreased from root up to the upper stem, and did not reach to the stem apex.

\section{Evaluation of the antifungal activity of the tested substances in vitro}

Antifungal activity of the tested substances against $F$. equiseti, F. incarnatum, $C$. trifolii and $R$. solani at different concentrations $(4,6,8,10,12$ and $14 \mathrm{mM})$ is presented in Table 3. Data show that there is an inverse relationship between the concentration of the tested substances and the linear growth of the tested fungi, so as when the concentration increases the linear growth decreases. Comparing with the control, SM was the best effective substance to decrease the growth of all tested fungi. Treatment with SM at a concentration of $10 \mathrm{mM}$ completely inhibited the growth of all tested fungi. Treatment with $\mathrm{HQ}$ came at the second rank, while SS showed to be the lowest substance as antifungal activity even at high concentrations.

\section{Monitoring disease severity}

In greenhouse, the best substances (HQ at 10 and $12 \mathrm{mM}$ and $\mathrm{SM}$ at 8 and $10 \mathrm{mM}$ ) were chosen according to in vitro experiments. The results presented here indicate that $\mathrm{HQ}$ and $S M$ at different concentrations significantly reduced the disease incidence in alfalfa plants infected with the tested pathogens (Table 4). Regarding to $R$. solani and $F$. equiseti, treatments of $\mathrm{HQ}$ at 10 and $12 \mathrm{mM}$ and $\mathrm{SM}$ at $8 \mathrm{mM}$ recorded the highest significant increase in the percentage of survived plants and consequently, the highest significant decrease in disease incidence percentage. SM at 8 and $10 \mathrm{mM}$ were the most effective 
Table 3. In vitro evaluation of the antifungal activity of tested substances.

\begin{tabular}{|c|c|c|c|c|c|c|c|c|c|}
\hline \multirow{2}{*}{\multicolumn{2}{|c|}{ Fungus }} & \multicolumn{8}{|c|}{ Colony diameter $(\mathrm{cm})$} \\
\hline & & \multicolumn{2}{|c|}{ F. equiseti } & \multicolumn{2}{|c|}{ F. incarnatum } & \multicolumn{2}{|c|}{ C. trifolii } & \multicolumn{2}{|c|}{ R. solani } \\
\hline Treatment & Conc. (mM) & 3 day & 5 day & 3 day & 5 day & 3 day & 5 day & 3 day & 5 day \\
\hline \multirow{7}{*}{ 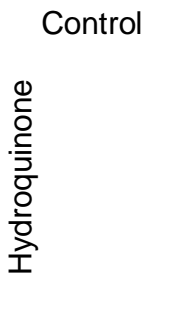 } & 0 & $5.6 \mathrm{a}$ & $8.9 \mathrm{a}$ & $4.4 \mathrm{a}$ & $8.1 \mathrm{a}$ & $3.4 \mathrm{a}$ & $5.6 \mathrm{a}$ & $7.9 \mathrm{a}$ & $9.0 \mathrm{a}$ \\
\hline & 4 & 3.0 ef & $5.8 \mathrm{e}$ & $2.9 \mathrm{f}$ & $4.7 f$ & $1.5 \mathrm{e}$ & $3.6 \mathrm{~d}$ & $6.0 \mathrm{e}$ & $8.4 \mathrm{c}$ \\
\hline & 6 & $2.9 \mathrm{f}$ & $5.7 \mathrm{e}$ & $2.4 \mathrm{~g}$ & $4.4 \mathrm{f}$ & $1.3 f$ & $3.4 \mathrm{~d}$ & $5.0 \mathrm{~g}$ & $7.2 \mathrm{~d}$ \\
\hline & 8 & $2.6 \mathrm{~g}$ & $5.2 f$ & $1.8 \mathrm{~h}$ & $3.6 \mathrm{~g}$ & $1.1 \mathrm{~g}$ & $2.9 \mathrm{e}$ & $4.0 \mathrm{~h}$ & $6.7 \mathrm{e}$ \\
\hline & 10 & $1.9 \mathrm{~h}$ & $5.0 \mathrm{f}$ & $1.3 \mathrm{i}$ & $3.4 \mathrm{~g}$ & $1.0 \mathrm{~h}$ & $2.5 f$ & $3.8 \mathrm{i}$ & $5.4 f$ \\
\hline & 12 & $1.7 \mathrm{i}$ & $4.4 \mathrm{~g}$ & $1.1 \mathrm{j}$ & $2.4 \mathrm{~h}$ & $0.7 \mathrm{i}$ & $1.3 \mathrm{~g}$ & $3.4 \mathrm{j}$ & $5.3 f$ \\
\hline & 14 & $1.3 \mathrm{j}$ & $3.5 \mathrm{~h}$ & $0.8 \mathrm{k}$ & $1.4 \mathrm{i}$ & $0.0 \mathrm{k}$ & $0.0 \mathrm{~h}$ & $3.1 \mathrm{k}$ & $4.6 \mathrm{~g}$ \\
\hline \multirow{6}{*}{ 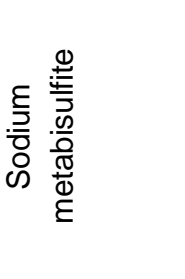 } & 4 & $3.7 \mathrm{~d}$ & $7.7 \mathrm{c}$ & $1.4 \mathrm{i}$ & $4.4 \mathrm{f}$ & $0.5 \mathrm{j}$ & $1.2 \mathrm{~g}$ & $3.5 \mathrm{j}$ & $6.5 \mathrm{e}$ \\
\hline & 6 & $0.7 \mathrm{k}$ & $1.3 \mathrm{i}$ & 0.01 & $0.0 \mathrm{j}$ & $0.0 \mathrm{k}$ & $0.0 \mathrm{~h}$ & 1.31 & $3.4 \mathrm{~h}$ \\
\hline & 8 & 0.01 & $0.0 \mathrm{j}$ & 0.01 & $0.0 \mathrm{j}$ & $0.0 \mathrm{k}$ & $0.0 \mathrm{~h}$ & $0.9 \mathrm{~m}$ & $1.7 \mathrm{i}$ \\
\hline & 10 & 0.01 & $0.0 \mathrm{j}$ & 0.01 & $0.0 \mathrm{j}$ & $0.0 \mathrm{k}$ & $0.0 \mathrm{~h}$ & $0.0 \mathrm{n}$ & $0.0 \mathrm{j}$ \\
\hline & 12 & 0.01 & $0.0 \mathrm{j}$ & 0.01 & $0.0 \mathrm{j}$ & $0.0 \mathrm{k}$ & $0.0 \mathrm{~h}$ & $0.0 \mathrm{n}$ & $0.0 \mathrm{j}$ \\
\hline & 14 & 0.01 & $0.0 \mathrm{j}$ & 0.01 & $0.0 \mathrm{j}$ & $0.0 \mathrm{k}$ & $0.0 \mathrm{~h}$ & $0.0 \mathrm{n}$ & $0.0 \mathrm{j}$ \\
\hline \multirow{6}{*}{ 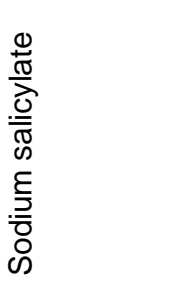 } & 4 & $5.4 \mathrm{a}$ & $8.4 \mathrm{~b}$ & $4.4 \mathrm{a}$ & $8.1 \mathrm{a}$ & $3.4 \mathrm{a}$ & $5.6 \mathrm{a}$ & $7.7 a b$ & $9.0 \mathrm{a}$ \\
\hline & 6 & $5.1 \mathrm{~b}$ & $8.3 \mathrm{~b}$ & $4.1 \mathrm{~b}$ & $7.4 \mathrm{~b}$ & $3.4 \mathrm{a}$ & $5.6 \mathrm{a}$ & $7.6 \mathrm{~b}$ & $9.0 \mathrm{a}$ \\
\hline & 8 & $4.1 \mathrm{c}$ & $7.9 \mathrm{c}$ & $3.9 \mathrm{c}$ & $6.8 \mathrm{c}$ & $3.3 \mathrm{~b}$ & $5.5 a b$ & $7.2 \mathrm{c}$ & $9.0 \mathrm{a}$ \\
\hline & 10 & $3.7 d$ & $7.0 \mathrm{~d}$ & $3.6 \mathrm{~d}$ & $6.7 \mathrm{c}$ & $3.3 \mathrm{~b}$ & $5.4 \mathrm{~b}$ & $6.3 d$ & $8.6 \mathrm{~b}$ \\
\hline & 12 & $3.2 \mathrm{e}$ & $5.8 \mathrm{e}$ & $3.4 \mathrm{e}$ & $6.4 \mathrm{~d}$ & $3.2 \mathrm{c}$ & $5.3 \mathrm{~b}$ & $6.0 \mathrm{e}$ & $7.3 \mathrm{~d}$ \\
\hline & 14 & $1.7 \mathrm{i}$ & $4.6 \mathrm{~g}$ & $3.0 \mathrm{f}$ & $6.0 \mathrm{e}$ & $3.1 \mathrm{~d}$ & $4.8 \mathrm{c}$ & $5.3 \mathrm{f}$ & $6.6 \mathrm{e}$ \\
\hline
\end{tabular}

Values within a column followed by the same letter(s) are not significantly different according to Duncan's multiple range test $(P \leq 0.05)$.

treatments in case of $C$. rolfesii, while, treatment of $\mathrm{HQ}$ at $12 \mathrm{mM}$ was the most effective one in case of $F$. incarnatum.

\section{Effect on growth parameters}

Data presented in Table 5 reveal that no significant differences were recorded on growth parameters of alfalfa plants (shoot length, branches and leaves number and shoot dry weight) when treated by $\mathrm{HQ}$ or SM at any concentration. Except treatments of $\mathrm{HQ}$ at $12 \mathrm{mM}$ and $\mathrm{SM}$ at $8 \mathrm{mM}$, no significant difference was recorded in the leaf area of alfalfa plants treated with the other treatments.

Comparing to the untreated infected plants, treatments of $\mathrm{HQ}$ or SM at any concentration increased all investigated growth parameters (except the number of branches) of alfalfa plants infected with $C$. trifolii or $R$. solani. On the other hand, no significant differences were recorded in all investigated growth parameters (except leaf area) of alfalfa plants infected with $F$. incarnatum and treated with $\mathrm{HQ}$ or SM at any concentration. In contrast, treatment with $\mathrm{HQ}$ or $\mathrm{SM}$ at any concentration of alfalfa plants infected with $F$. equiseti significantly decreased both of number of branches and shoot dry weight, while, no significant difference was recorded in the shoot length when compared with the untreated-infected plants.

\section{Photosynthetic pigments}

The photosynthetic pigments of alfalfa plants showed different responses to the tested substances (Table 6). No significant differences were founded in the photosynthetic pigments of the non infected alfalfa leaves when treated with $\mathrm{HQ}$ at 10 and $12 \mathrm{mM}$ or $\mathrm{SM}$ at $10 \mathrm{mM}$, while, treatment with $\mathrm{SM}$ at $8 \mathrm{mM}$ led to a significant decrease in the photosynthetic pigments.

Results obtained indicated that, treatments with $\mathrm{HQ}$ or $\mathrm{SM}$ at any concentration led to a significant increase in the photosynthetic pigments of alfalfa plants infected with C. trifolii, $R$. solani or F. incarnatum. Except the treatment with SM $8 \mathrm{mM}$, all treatments led to a significant increase in the photosynthetic pigments of alfalfa plants infected with $F$. equiseti.

\section{Total phenol content}

No significant differences were recorded in the total phenol content of the non-infected alfalfa plants treated 
Table 4. Effect of $\mathrm{HQ}$ and $\mathrm{SM}$ on disease incidence of alfalfa under greenhouse conditions.

\begin{tabular}{|c|c|c|c|c|c|c|c|}
\hline \multirow{2}{*}{ Fungus } & \multirow{2}{*}{ Symptom } & \multicolumn{6}{|c|}{ Treatment } \\
\hline & & $\mathbf{P}^{*}$ & $\mathbf{F}+\mathbf{P}$ & P+ HQ10 & P+ HQ12 & $P+S M 8$ & P+ SM10 \\
\hline \multirow{3}{*}{ C. trifolii } & Pre-emergence & 37.7 & 21.9 & 22.3 & 20.0 & 18.3 & 18.0 \\
\hline & Post-emergence & 22.3 & 18.0 & 14.4 & 15.0 & 7.7 & 12.0 \\
\hline & Survival & 40.0 & 60.1 & 63.0 & 65.0 & 73.3 & 70.0 \\
\hline \multirow{3}{*}{ R. solani } & Pre-emergence & 33.3 & 22.0 & 14.0 & 18.3 & 16.2 & 18.3 \\
\hline & Post-emergence & 21.1 & 15.9 & 11.7 & 11.7 & 15.1 & 17.1 \\
\hline & Survival & 45.6 & 62.1 & 70.0 & 70.0 & 68.8 & 64.6 \\
\hline \multirow{3}{*}{ F. equiseti } & Pre-emergence & 16.7 & 15.7 & 10.5 & 16.6 & 16.1 & 17.8 \\
\hline & Post-emergence & 14.4 & 9.2 & 9.5 & 11.1 & 7.2 & 13.3 \\
\hline & Survival & 68.9 & 75.0 & 80.0 & 72.3 & 76.7 & 68.9 \\
\hline \multirow{3}{*}{ F. incarnatum } & Pre-emergence & 26.6 & 14.1 & 13.9 & 11.1 & 18.1 & 18.8 \\
\hline & Post-emergence & 15.1 & 10.4 & 9.4 & 7.8 & 11.9 & 12.2 \\
\hline & Survival & 58.3 & 75.4 & 76.7 & 81.1 & 70.0 & 68.9 \\
\hline \multirow{3}{*}{ Control } & Pre-emergence & 2.7 & & & & & \\
\hline & Post-emergence & 0.0 & & & & & \\
\hline & Survival & 97.3 & & & & & \\
\hline
\end{tabular}

Each value represents the mean of 10 replicates (10 seeds each), where, $P=$ pathogen, $F=$ chemical fungicide, HQ10 - HQ12= hydroquinone at 10 and $12 \mathrm{mM}$, and SM8 - SM10 = sodium metabisulfite at 8 and $10 \mathrm{mM}$, respectively.

L.S.D. at $0.05=6.016$ for pre-emergence damping-off, 5.499 for post-emergence damping-off and 7.442 for Survival seedlings.

with $\mathrm{HQ}$ or $\mathrm{SM}$ at any concentration (Table 7). On the other hand, treatments with $\mathrm{HQ}$ or SM at any concentration led to a significant increase in total phenol contents in shoots of alfalfa plants infected with $C$. trifolii and $F$. equiseti. Except the treatment with SM $10 \mathrm{mM}$, all treatments led to a significant increase in the total phenol content of alfalfa plants infected with $F$. incarnatum when compared to the untreated-infected treatment. Regarding to alfalfa plants infected with $R$. solani, treatment with $\mathrm{HQ}$ at 10 or $12 \mathrm{mM}$ showed significantly increases in the total phenol content, while, no significant difference was recorded when seeds were treated with SM at 8 or $10 \mathrm{mM}$.

\section{DISCUSSION}

Pathogenicity test indicated that $R$. solani and $C$. trifolii were the most devastating fungi causing $26.45,26.1 \%$, seed infection and $31.6,21.1 \%$ seedling mortality, respectively. This was followed by $F$. equiseti and $F$. incarnatum, in seed inoculation experiments. Results of the transmission study showed that the recovery percentages of the tested pathogens gradually decreased from root apex up to the first internodes below the shoot tip, but did not reach to the shoot apex. These results are in agreement with that of Frate and Davis (2007) who reported that $C$. trifolii spores may spread by seed during the threshing process to infect the growing stem and petioles of alfalfa plant. Al-Kherb et al. (1997) confirmed these results by positive serial isolations made up of $R$. solani from roots, crowns and stems of infected alfalfa plants. There was a direct correlation between seed infection and loss in germination. Moreover, Krnjaja et al. (2005) studied the virulence of 91 isolates of different species of Fusarium on alfalfa seedlings. Isolates of $F$. equiseti demonstrated weak virulence (necrosis on the tip of the root), while isolates of species $F$. incarnatum demonstrated medium virulence (root and low part of the stem while necrosis did not spread on leaves or on the upper section of stem). These results were previously explained by Neergaard (1979), since he reported that the pathogens either extra-embryonal or embryonal, since infection was able to cause seed rot, seedling mortality and finally death of seedlings. In this case the pathogen may spread from primary infection (seeds) to leaves, petioles and stems, where they germinate, the hypha penetrating the host and producing local infection (example A. alternata) or lives for period of time saprophytically, persists in a resting stage in the soil or in plant residues and infects the host at a later time example, Phoma sp., R. solani and Fusarium species. Since most fungi affect alfalfa is seed-borne, the movement of seeds for commerce exchange greatly increases opportunities for long distance dispersal and permanent establishment of pathogens in new areas (Vasić et al., 2011). 
Table 5. Growth parameters of infected alfalfa plants treated with different treatments.

\begin{tabular}{|c|c|c|c|c|c|c|c|}
\hline \multirow{2}{*}{ Fungus } & \multirow{2}{*}{ Growth parameter } & \multicolumn{6}{|c|}{ Treatment } \\
\hline & & $\mathbf{P}$ & $\mathbf{F + P}$ & $\mathrm{P}+\mathrm{HQ10}$ & $\mathrm{P}+\mathrm{HQ12}$ & $\mathrm{P}+\mathrm{SM} 8$ & P+SM10 \\
\hline \multirow{5}{*}{ 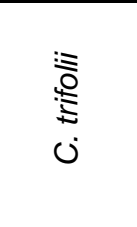 } & Shoot length $(\mathrm{cm})$ & 20.6 & 32.3 & 25.7 & 24.9 & 23.2 & 24.8 \\
\hline & No. of branches & 1.3 & 2.0 & 2.2 & 2.3 & 1.8 & 2.3 \\
\hline & No. of leaves & 12.8 & 16.5 & 18.2 & 19.5 & 17.8 & 20.8 \\
\hline & Leaf area $(\mathrm{cm} 2)$ & 25.3 & 65.4 & 69.1 & 48.6 & 43.8 & 59.3 \\
\hline & Shoot dry weight (g) & 0.31 & 0.33 & 0.39 & 0.48 & 0.47 & 0.38 \\
\hline \multirow{5}{*}{ 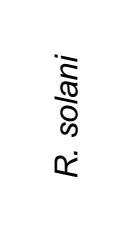 } & Shoot length $(\mathrm{cm})$ & 25.3 & 23.2 & 26.5 & 25.0 & 23.9 & 25.1 \\
\hline & No. of branches & 2.1 & 2.3 & 2.0 & 2.1 & 2.8 & 2.3 \\
\hline & No. of leaves & 17.8 & 18.0 & 18.3 & 17.0 & 21.1 & 20.6 \\
\hline & Leaf area $(\mathrm{cm} 2)$ & 39.1 & 56.7 & 68.4 & 45.8 & 72.4 & 70.8 \\
\hline & Shoot dry weight (g) & 0.20 & 0.30 & 0.31 & 0.27 & 0.26 & 0.30 \\
\hline \multirow{5}{*}{ 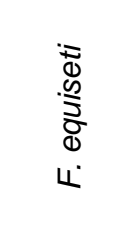 } & Shoot length $(\mathrm{cm})$ & 26.3 & 25.2 & 35.2 & 28.8 & 27.7 & 27.0 \\
\hline & No. of branches & 2.7 & 1.2 & 1.8 & 1.3 & 2.1 & 2.0 \\
\hline & No. of leaves & 21.0 & 18.6 & 18.5 & 24.5 & 21.1 & 17.1 \\
\hline & Leaf area $(\mathrm{cm} 2)$ & 79.4 & 72.4 & 80.9 & 43.9 & 69.4 & 84.6 \\
\hline & Shoot dry weight (g) & 0.49 & 0.25 & 0.39 & 0.37 & 0.30 & 0.37 \\
\hline \multirow{5}{*}{ 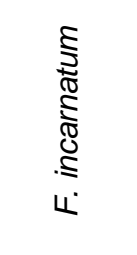 } & Shoot length $(\mathrm{cm})$ & 20.6 & 21.3 & 33.0 & 31.5 & 24. & 25.7 \\
\hline & No. of branches & 1.5 & 1.8 & 1.8 & 1.9 & 2.0 & 2.7 \\
\hline & No. of leaves & 14.3 & 16.7 & 21.7 & 21.7 & 17.0 & 21.7 \\
\hline & Leaf area $(\mathrm{cm} 2)$ & 29.3 & 36.1 & 54.1 & 41.4 & 37.4 & 48.1 \\
\hline & Shoot dry weight (g) & 0.22 & 0.28 & 0.36 & 0.37 & 0.37 & 0.39 \\
\hline \multirow{6}{*}{ 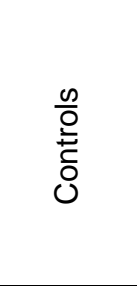 } & & C & $\mathbf{F}$ & HQ10 & HQ12 & SM8 & SM10 \\
\hline & Shoot length $(\mathrm{cm})$ & 26.3 & 29.4 & 26.3 & 29.6 & 26.1 & 29.3 \\
\hline & No. of branches & 2.7 & 2.5 & 2.7 & 2.2 & 19.0 & 2.0 \\
\hline & No. of leaves & 21.0 & 21.5 & 22.7 & 20.2 & 94.2 & 19.0 \\
\hline & Leaf area $(\mathrm{cm} 2)$ & 79.4 & 76.5 & 83.9 & 94.4 & 0.40 & 65.8 \\
\hline & Shoot dry weight $(\mathrm{g})$ & 0.49 & 0.48 & 0.53 & 0.41 & 0.40 & 0.35 \\
\hline
\end{tabular}

Each value represents the mean of 10 replicates (10 seeds each), where, $C=$ control, $F=$ chemical fungicide, $P=$ pathogen, $\mathrm{HQ} 10-\mathrm{HQ} 12=$ hydroquinone at 10 and $12 \mathrm{mM}$, and SM8 - SM10= sodium metabisulfite at 8 and $10 \mathrm{mM}$, respectively.

L.S.D. at $0.05=3.632$ for shoot length, 0.873 for no. of branches, 4.282 for no. of leaves, 11.311 for leaf area and 0.118 for dry weight.

The antifungal activity of the three tested substances (HQ, SS and SM) investigated in this study showed that SM was the most effective one in inhibiting the target fungi. This result is in agreement with that of Mills et al. (2004) who received the same results on Alternaria alternata, Botrytis cinerea, F. solani, Phytophthora erythroseptica, P. infestans, Verticillium albo-atrum, and V. dahlia. Also, Latifa et al. (2011) and Talibi et al. (2011) reported that SM has completely inhibited growth and spore germination of Penicillium italicum and Geotrichum candidum, respectively. The mechanisms thought to be responsible for the sodium metabisulfite inhibition of fungal growth were explained on the basis of cell disruption and compromised membrane permeability (Avis et al., 2009). An investigation using transmission electron microscope showed some ultrastructural alterations including membrane retraction, undulation, and invagination, loss of membrane integrity, cytoplasmic leakage, and cell rupture in the affected cells (Avis et al., 2009). In addition, recent results with $F$. sambucinum, $P$. infestans, and $R$. solani exposed to sodium metabisulfite indicated that lipid peroxidation damage of fatty acids or fatty acyl chains would be involved in the antifungal mode of action (Avis et al., 2007).

Hydroquinone comes at the second rank of SM in inhibiting the growth of alfalfa seed-borne pathogens. In this connection, at $14 \mathrm{mM}$, they completely inhibited the linear growth of $C$. trifolii. The obtained results are in 
Table 6. Photosynthetic pigments ( $\mathrm{mg} \mathrm{g}^{-1}$ fresh weight) in infected alfalfa leaves treated with different treatments.

\begin{tabular}{|c|c|c|c|c|c|c|c|}
\hline \multirow{2}{*}{ Fungus } & \multirow{2}{*}{ Growth parameter } & \multicolumn{6}{|c|}{ Treatment } \\
\hline & & $\mathbf{P}$ & $\mathbf{F}+\mathbf{P}$ & $\mathrm{P}+\mathrm{HQ10}$ & $\mathrm{P}+\mathrm{HQ12}$ & P+SM8 & P+SM10 \\
\hline \multirow{4}{*}{ C. trifolii } & Chl. a & 1.09 & 1.36 & 1.58 & 1.36 & 1.46 & 1.29 \\
\hline & Chl. b & 0.78 & 0.96 & 1.28 & 1.27 & 1.15 & 1.07 \\
\hline & Total Chl. & 1.87 & 2.32 & 2.86 & 2.62 & 2.61 & 2.36 \\
\hline & Carotenoids & 0.57 & 0.69 & 0.84 & 0.79 & 0.76 & 0.7 \\
\hline \multirow{4}{*}{ R. solani } & Chl. a & 1.23 & 1.34 & 1.51 & 1.37 & 1.59 & 1.54 \\
\hline & Chl. b & 0.87 & 0.88 & 1.22 & 1.09 & 1.34 & 1.24 \\
\hline & Total Chl. & 2.1 & 2.22 & 2.73 & 2.46 & 2.93 & 2.78 \\
\hline & Carotenoids & 0.65 & 0.66 & 0.82 & 0.72 & 0.86 & 0.82 \\
\hline \multirow{4}{*}{ F. equiseti } & Chl. a & 1.27 & 1.58 & 1.69 & 1.59 & 1.39 & 1.58 \\
\hline & Chl. b & 1.01 & 1.18 & 1.38 & 1.36 & 0.76 & 1.36 \\
\hline & Total Chl. & 2.28 & 2.76 & 3.07 & 2.95 & 2.16 & 2.94 \\
\hline & Carotenoids & 0.68 & 0.81 & 0.89 & 0.9 & 0.56 & 0.87 \\
\hline \multirow{4}{*}{$\begin{array}{l}\text { F. } \\
\text { incarnatum }\end{array}$} & Chl. a & 1.18 & 1.26 & 1.43 & 1.47 & 1.4 & 1.67 \\
\hline & Chl. b & 0.71 & 0.92 & 0.88 & 1.14 & 1.28 & 1.25 \\
\hline & Total Chl. & 1.89 & 2.18 & 2.31 & 2.61 & 2.68 & 2.92 \\
\hline & Carotenoids & 0.57 & 0.67 & 0.69 & 0.79 & 0.81 & 0.85 \\
\hline Controls & & C & $\mathbf{F}$ & HQ10 & HQ12 & SM8 & SM10 \\
\hline Chl. a & & 1.74 & 1.25 & 1.62 & 1.57 & 1.23 & 1.62 \\
\hline Chl. b & & 1.08 & 0.95 & 1.29 & 1.26 & 0.76 & 1.26 \\
\hline Total Chl. & & 2.81 & 2.19 & 2.9 & 2.86 & 2 & 2.88 \\
\hline Carotenoids & & 0.84 & 0.67 & 0.83 & 0.84 & 0.59 & 0.85 \\
\hline
\end{tabular}

Each value represents the mean of 10 replicates ( 10 seeds each), where, $\mathrm{C}=$ control (uninfested sterilized soil), $\mathrm{F}=$ chemical fungicide, $\mathrm{P}=$ pathogen, HQ10 $-\mathrm{HQ} 12$ = hydroquinone at 10 and $12 \mathrm{mM}$, and SM8 - SM10= sodium metabisulfite at 8 and $10 \mathrm{mM}$, respectively.

L.S.D. at $0.05=0.2060$ for chl. a, 0.2341 for chl. b, 0.3778 for total chl. and 0.1048 for carotenoids.

Table 7. Total phenol content (mg $100 \mathrm{~g}^{-1}$ fresh weight) in infected alfalfa leaves treated with different treatments.

\begin{tabular}{lcccccc}
\hline \multirow{2}{*}{ Fungus } & $\mathbf{7}$ Treatment \\
\cline { 2 - 7 } & $\mathbf{P}$ & $\mathbf{F + P}$ & $\mathbf{P + H Q 1 0}$ & $\mathbf{P + H Q 1 2}$ & $\mathbf{P + S M 8}$ & $\mathbf{P + S M 1 0}$ \\
\hline C. trifolii & $68.4 \mathrm{e}$ & $91.2 \mathrm{a}-\mathrm{C}$ & $97.9 \mathrm{ab}$ & $79.7 \mathrm{c}-\mathrm{e}$ & $99.8 \mathrm{ab}$ & $105.8 \mathrm{a}$ \\
R. solani & $66.7 \mathrm{c}$ & $71.5 \mathrm{c}$ & $96.6 \mathrm{a}$ & $75.5 \mathrm{bc}$ & $71.2 \mathrm{c}$ & $67.4 \mathrm{c}$ \\
F. equiseti & $58.9 \mathrm{f}$ & $96.5 \mathrm{ab}$ & $92.0 \mathrm{a}-\mathrm{C}$ & $83.7 \mathrm{~b}-\mathrm{e}$ & $105.4 \mathrm{a}$ & $92.3 \mathrm{a}-\mathrm{c}$ \\
F. incarnatum & $77.3 \mathrm{~b}-\mathrm{d}$ & $99.9 \mathrm{a}$ & $85.5 \mathrm{a}-\mathrm{d}$ & $92.3 \mathrm{ab}$ & $85.6 \mathrm{a}-\mathrm{d}$ & $78.8 \mathrm{~b}-\mathrm{d}$ \\
Controls & $\mathbf{C}$ & $\mathbf{F}$ & HQ10 & HQ12 & SM8 & SM10 \\
& $72.1 \mathrm{de}$ & $87.4 \mathrm{~b}-\mathrm{d}$ & $80.9 \mathrm{c}-\mathrm{e}$ & $87.7 \mathrm{~b}-\mathrm{d}$ & $77.4 \mathrm{c}-\mathrm{e}$ & $70.2 \mathrm{e}$ \\
\hline
\end{tabular}

Each value represents the mean of 10 replicates (10 seeds each), where, $\mathrm{C}=$ control (uninfested sterilized soil), $\mathrm{F}=$ chemical fungicide, $\mathrm{P}=$ pathogen, $\mathrm{HQ10}-\mathrm{HQ12}=$ hydroquinone at 10 and $12 \mathrm{mM}$, and SM 8 - SM10 = sodium metabisulfite at 8 and $10 \mathrm{mM}$, respectively.

Values within a raw followed by the same letter(s) are not significantly different according to Duncan's multiple range test $(P \leq 0.05)$.

agreement with the finding of El-Wakil and El-Metwally (2000) against seed-borne pathogenic fungi (Cephalosporium sp, F. moniliforme, F. oxysporum, F. solani, R. solani, Sclerotium bataticola and Verticillum sp.) of peanut. Also, Ali et al. (2009) reported that HQ reduced significantly the mycelial growth of root rot pathogenic fungi 
attacking lupine plants. Cowan (1999) explained the mechanisms thought to be responsible for the phenolics toxicity to microorganisms on the basis of enzyme inhibition by the oxidized compounds, possibly through reaction with sulfohydryl groups or through more nonspecific interactions with the proteins. The sites and number of hydroxyl groups on the phenol compounds like hydroqui-none are thought to be related to their relative toxicity to microorganisms, with evidence that increased hydroxylation associated with increased toxicity. In addition, Scalbert (1991) has found that the more highly oxidized phenols are the more inhibitory effect to the pathogen.

Under greenhouse conditions, treatment with $\mathrm{HQ}$ at 12 $\mathrm{mM}$ was the best. Where, the treated-infected alfalfa plants showed the lowest level of mortality percentage and the highest plant survival percentage. Moreover, treatment with $\mathrm{HQ}$ significantly improved the tested growth parameters (shoot length, number of leaves and shoot dry weight) when compared with the control. The obtained results are in agreement with the findings of El-Wakil (2003) who showed that hydroquinone not only inhibits the peanut seed-borne fungi but also has an effect in improving the growth of the plants and raise the yield by up to $50 \%$ more comparing to the untreated treatments. This phenomenon has also been shown by Chinese authors (Boeckx et al., 2000) who indicated that hydroquinone function as urease inhibitor and improve the urea $\mathrm{N}$ recovery by spring wheat with $34 \%$ as com-pared to the treatment where only urea was applied. It also improved the quality (protein $\mathrm{N}$ content) of the grain.

Alfalfa plants that were treated with $\mathrm{HQ}$ showed significant increase in the total photosynthetic pigments and the total phenol contents. Increasing photosynthetic pigments will expected to increase carbohydrate content in plant tissues. This important action greatly affects pectin that consider a barrier against plant pathogens invasion and phenolic compounds, which play a major and important role in plant defense (Hahlbrock and Scheel, 1989). In addition, the enhancement in chlorophell content increases disease resistance as well as decreases photophosphorylation rate, which occurred after infection (Amaresh and Bhatt, 1988). Plants can tolerate infection by increasing the chlorophyll concentration in leaves. Most plants produce a broad range of secondary metabolites (ex. phenolic and polyphenolic compounds) that are toxic to pathogens, either as part of their normal program of growth and development or in response to biotic stress (Lattanzio et al., 2006). In this connection, Ali et al. (2009) reported that, total phenols content in lupine leaves significantly increased by $\mathrm{HQ}$ application. Phenolics are well-known as antifungal, antibacterial and antiviral compounds occur naturally in plants (Lattanzio et al., 2006). According to Vermerris and Nicholson (2006), the first step of the defense mechanism in plants involves a rapid accumulation of phenols at the infection site, which restricts or slows the growth of the pathogen. Yet total phenols have long been considered as important defense-related compounds whose levels are naturally high in resistant varieties of many crops (Vermerris and Nicholson, 2006). Based on these results we recommend applying these treatments in order to control the seedborne diseases of alfalfa as alternative to chemical fungicides due to its safety, effectiveness and inexpensiveness.

\section{ACKNOWLEDGMENT}

The authors extend their appreciation to the Deanship of Scientific Research at King Saud University for funding this work. The authors thank Professor Wesam I.A. Saber, Microbiology Department, Soils, Water, Environment Research Institute, Agriculture Research Center for critical review of manuscript.

\section{REFERENCES}

Abd El-Hai KM, El-Metwally MA, El-Baz SM, Zeid AM (2009). The use of antioxidants and microelements for controlling damping-off caused by Rhizoctonia solani and charcoal rot caused by Macrophomina phaseoliana on sunflower. Plant Pathol. J. 8(3):79-89.

Agriculture Statistical Yearbook (2012). Ministry of Agriculture. Volume 24, Saudi Arabia.

Al-Askar AA, Ghoneem KM, Rashad YM (2012). Seed-borne mycoflora of alfalfa (Medicago sativa L.) in the Riyadh Region of Saudi Arabia. Ann. Microbiol. 62: 273-281.

Ali AA, Ghoneem KM, El-Metwally MA, Abd El-Hai KM (2009). Induce systemic resistance in lupine against root rot diseases. Pakistan J. Biol. Sci. 12(3): 231-221.

Al-Kherb S, Al-Doss A, El-Hussieni S (1997). Identification of Anastomosis Group of Rhizoctonia solani Kuhn Causing Alfalfa Root Canker in Riyadh Area of the Kingdom of Saudi Arabia. J. King Saudi Univ. Agric. Sci. 9(2): 337-340.

Amaresh C, Bhatt RK (1988). Biochemical and physiological response to salicylic acid in reaction to systemic acquired resistance. Photosynthetica, 35: 255-258.

Ash M, Ash I (2009). Handbook of Preservatives. Synapse Information Resources, Inc.

Avis TJ, Michaud M, Tweddell RJ (2007). Role of lipid composition and lipid peroxidation in the sensitivity of fungal plant pathogens to aluminum chloride and sodium metabisulfite. Appl. Environ. Microbiol. 73:2820-2824.

Avis TJ, Rioux D, Simard M, Michaud M, Tweddell RJ (2009). Ultrastructural alterations in Fusarium sambucinum and Heterobasidion annosum treated with aluminum chloride and sodium metabisulfite. Phytopathology 99:167-175.

Boeckx P, Xu X, Zhou L, van Cleemput O, Shi Y (2000). Mededelingen $B$ faculteit landbouwkundige en toegepaste biologische wetenschappen. Univ. Gent., 65: 47-52.

Booth C (1977). The genus Fusarium. Commonwealth Mycological Institute, Kew. Surrey, England.

CoStat (2005). Cohort Software, 798 Lighthouse Ave. PMB 320 Monterey, USA.

Couture L, Dhont C, Chalifour F-P, Drapeau R, Tremblay G, Castonguay Y, Bélanger, G, Nadeau P (2002). Fusarium root and crown rot in alfalfa subjected to autumn harvests. Can. J. Plant Sci. 82: $621-624$.

Cowan MM (1999). Plant products as Antimicrobial agents. Clin. Microbiol. Rev. 12, 564-582.

Domsch KH, Gams W, Anderson TH (1980). Compendium of Soil Fungi. Vols. 1, 2. Academic Press, New York.

Duncan DB (1955). Multiple range and multiple F test. Biometrics. 11: 124.

El-Wakil M, El-Metwally M (2000). Hydroquinone, a promising antioxidant for managing seed-borne pathogenic fungi of peanut. Pak. J. Biol. Sci. 3: 374-375. 
Elwakil MA (2003). Use of Antioxidant Hydroquinone in the Control of Seed-borne Fungi of Peanut with Special Reference to the Production of Good Quality Seed. Plant Pathol. J. 2: 75-79.

Frate CA, Davis RM (2007). Alfalfa diseases and management. In C.G. Summers and D.H. Putman, eds., Irrigated alfalfa management for Mediterranean and Desert Zones. Chapter 10. Oakland: University of California Agriculture and Natural Resources Publication 8296.

Goswami RS, Dong Y, Punja ZK (2008). Host range and mycotoxin production by Fusarium equiseti isolates originating from ginseng fields. Can. J. Plant Pathol. 30: 155-160.

Hahlbrock K, Scheel D (1989). Physiology and molecular biology of phenyl propanoid metabolism. Ann. Rev. Plant Physiol. Plant Mol. Biol. 40: 347-369.

Harborne JB (1984). Phytochemical Methods: a guide modern techniques of plant analysis. Chapman and Hall press, London.

Hervieux V, Yaganza ES, Arul J, Tweddell RJ (2002). Effect of organic and inorganic salts on the development of Helminthosporium solani, the causal agent of potato silver scurf. Plant Dis. 86, 1014-1018.

ISTA (International Seed Testing Association) (1999). International Rules for Seed Testing. Seed Sci. Technol. (Suppl.) 24: 1-335.

Krnjaja V, Leviã J, Ivanoviã M, Tomiã Z (2003). Fusarium species associated with seeds of alfalfa cultivars. Czech J. Genet. Plant Breeding, Special Issue, 39: 275-278.

Krnjaja V, Lević J, Ivanović M, Zorica P (2005). Virulence of Fusarium species to alfalfa seedlings. Matica Srpska Proceedings for Natural Sciences, 107: 167-171.

Latifa A, Idriss T, Hassan B, Amine SM, El Hassane B, Abdellah ABA (2011). Effect of organic acids and salts on the development of Penicillium italicum: the causal agent of citrus blue mold. Plant Pathol. J. 10(3): 99-107.

Lattanzio V, Lattanzio VMT, Cardinali A (2006). Role of phenolics in the resistance mechanisms of plants against fungal pathogens and insects. In Phytochemistry: Advances in Research ( $F$. Imperato, ed.), pp. 23-67. Trivandrum, Kerala, India: Research Signpost.

Malik CP, Singh MB (1980). Plant Enzymology and Histoenzymology. Kalyani Publishers, New Delhi, p. 53.

Mathur SB, Manandhar HK (2003). Fungi in seeds: Recorded at The Danish Government Institute of Seed Pathology for Developing Countries. Kandrups Bogtrykkeri, Århusgade 88, DK-2100 Copenhagen, Denmark.

Mills AAS, Platt HW, Hurta RAR (2004). Effect of salt compounds on mycelial growth, sporulation and spore germination of various potato pathogens. Postharvest Biol. and Technol. 34:341-350.
Neergaard P (1979). Seed Pathology. The MacMillan Press Ltd., London.

O'Neill NR, Saunders JA (1994). Compatible and incompatibl e responses in alfalfa cotyledons to races I and 2 of Colletotrichum trifolii. Phytopathology 84: 283-287.

Scalbert A (1991). Antimicrobial properties of tannins. Phytochemistry 30: 3875-3883.

Shabana YM, Abdel-Fattah GM, Ismail AE, Rashad YM (2008). Control of brown spot pathogen of rice (Bipolaris oryzae) using some phenolic antioxidants. Braz. J. Microbiol. 39:438-444.

Talibi I, Askarne L, Boubaker H, Boudyach E, Aoumar AAB (2011). In vitro and in vivo antifungal activities of organic and inorganic salts against citrus sour rot agent Geotrichum candidum. Plant Pathology J. 10(4): 138-145.

Thomas GJ, Sweetingham MW (2003). Fungicide seed treatments reduce seed transmission and severity of lupin anthracnose caused by Colletotrichum gloeosporioides. Australasian Plant Pathol. 32(1): 39-46.

Vasić T, Anđelković S, Živković S, Anđelković B, Terzić D, Milenković J (2011). Appearance and frequence of fungi on alfalfa seed in Serbia. Biotechnol. Anim. Husbandry, 27 (4): 1579-1584

Vasić T, Radović J, Lugić Z, Marković J, Jevtić G, Gajić S (2010). Occurrence of Colletotrichum trifolii (Bain et Essary), the Inducer of Alfalfa Anthracnose in Serbia. In: Huyghe, C. (Ed.), Sustainable use of Genetic Diversity in Forage and Turf Breeding: Part 4: 369-374. Springer Dordrecht Heidelberg London New York.

Vermerris W, Nicholson R (2006). The Role of Phenols in Plant Defense. In: Phenolic Compound Biochemistry, Vermerris, W. and R. Nicholson (Eds.). Springer, Dordrecht, The Netherlands. pp: 211-234.

Zaccardelli M, Balmas V, Altomare C, Corazza L, Scotti C (2006). Characterization of Italian isolates of Fusarium semitectum from alfalfa (Medicago sativa L.) by AFLP analysis, morphology, pathogenicity and toxin production. J. Phytopathol. 154: 454-460. 